\title{
Dampak Harga Produk, Promosi, Lokasi Dan Layanan Terhadap Keputusan Pembelian
}

\author{
Ahmad Zaini, Nurul Qomariah, dan Budi Santoso \\ Universitas Muhammadiyah Jember \\ Email: nurulqomariah@unmuhjember.ac.id, dan budisantoso@unmuhjember.ac.id \\ Diterima: Desember 2019; Dipublikasikan Januari 2020
}

\begin{abstract}
ABSTRAK
Penelitian ini bertujuan mengetahui pengaruh harga $\left(X_{1}\right)$, produk $\left(X_{2}\right)$, promosi $\left(X_{3}\right)$, lokasi $\left(\mathrm{X}_{4}\right)$ dan layanan $\left(\mathrm{X}_{5}\right)$ terhadap keputusan pembelian $(\mathrm{Y})$. pada pelanggan Warung Cak Wang Jember. Populasi dalam penelitian ini adalah semua pelanggan yang pernah melakukan pembelian pada Warung Kopi Cak Wang Jember. Jumlah sampel berjumlah sebanyak 60 sampel, dengan metode pengambilan sampel menggunakan metode purposive sampling. Alat ukur diuji dengan menggunakan uji validitas dan uji validitas. Untuk mengetahui pengaruh variabel bebas terhadap variabel terikat digunakan analisis regresi linear berganda. Hasil penelitian menunjukkan bahwa harga, produk, promosi, lokasi dan layanan berpengaruh signifikan secara parsial terhadap keputusan pembelian pad "Warung Kopi Cak Wang" Jember.
\end{abstract}

Kata Kunci: harga; produk; promosi; lokasi, layanan; keputusan pembelian

\begin{abstract}
This study aims to determine the effect of price (X1), product (X2), promotion (X3), location (X4) and service (X5) on purchasing decisions (Y). to the customers of Warung Cak Wang Jember. The population in this study are all customers who have made purchases at the Cak Wang Jember Coffee Shop. The number of samples amounted to 60 samples, with the sampling method using purposive sampling method. Measuring instruments are tested using the validity test and validity test. To determine the effect of independent variables on the dependent variable used multiple linear regression analysis. The results showed that price, product, promotion, location and services had a partially significant effect on purchasing decisions on "Warung Kopi Cak Wang" Jember.
\end{abstract}

Keywords: price, product, promotion, location, service and purchasing decision 


\section{PENDAHULUAN}

Perkembangan bisnis di era Abad ke-21 telah berkembang sangat pesat dan mengalami metamorfosis yang berkesinambungan. Setiap pelaku usaha di setiap kategori bisnis, dituntut untuk memiliki kepekaan terhadap setiap perubahan yang terjadi dan menempatkan orientasi kepada kepuasan pelanggan sebagai tujuan utama (Kotler \& Keller, 2009). Tidak terkecuali usaha dalam penyajian makanan dan minuman (food service) yang dimulai dari skala kecil seperti warung-warung dan kafe tenda; bisnis makanan berskala menengah seperti depot, rumah makan dan kafe; sampai dengan bisnis makanan yang berskala besar seperti restoran-restoran di hotel berbintang. Para pelaku bisnis harus menyiapkan strategi agar dapat menyenangkan hati dan membangun rasa antusias kepada konsumen adalah menjadi suatu experience di dalam mengkonsumsi produk dan jasa, sehingga akan membuat mereka terkesan. Oleh karena itu diperlukannya sebuah paradigma untuk menggeser sebuah pemikiran tradisional dalam kategori bisnis food service, yang sebelumnya hanya menyediakan menu hidangan (makanan dan minuman) saja menjadi sebuah konsep modern yang menawarkan suatu pengalaman tak terlupakan.

Semakin ketatnya persaingan bisnis yang ada, terutama persaingan yang berasal dari perusahaan sejenis, membuat perusahaan semakin dituntut agar bergerak lebih cepat dalam hal untuk menarik konsumen. Sehingga perusahaan yang menerapkan konsep pemasaran perlu mencermati perilaku konsumen dan faktor-faktor yang mempengaruhi keputusan pembeliannya dalam usaha-usaha pemasaran sebuah produk yang dilakukan. Hal tersebut dikarenakan dalam konsep, salah satu cara untuk mencapai tujuan perusahaan adalah dengan mengetahui apa kebutuhan dan keinginan konsumen atau pasar sasaran serta memberikan kepuasan yang diharapkan secara lebih efektif dan efisien dibandingkan para pesaing (Kotler \& Armstrong, 2012).

Coffee atau kopi dalam bahasa Indonesia secara luas dikenal sebagai minuman stimulan yang dibuat dari biji kopi. Saat ini kopi adalah salah satu minuman yang paling terkenal didunia. Tanaman kopi bukan tanaman asli Indonesia, melainkan jenis tanaman yang berasal dari benua Afrika. Tanaman kopi dibawa ke pulau Jawa pada tahun 1696. Indonesia diberkati dengan letak geografisnya yang sangat cocok bagi tanaman kopi. Letak Indonesia sangat ideal bagi iklim mikro untuk pertumbuhan dan produksi kopi. Indonesia menghasilkan 420.000 metric ton kopi ditahun 2007, dari hasil tersebut sekitar 271.000 ton diekspor dan selebihnya untuk dikonsumsi dalam negeri. Untuk ekspor, sekitar 25\% adalah kopi Arabica yang dikenal bermutu tinggi sehingga digunakan untuk campuran kopi sejenis yang berasal dari Amerika Tengah dan Afrika Timur yang mempunyai "acidity coffee" yang tinggi. Ada beberapa varietas kopi. Mereka berbeda dalam kualitas, rasa, dan selera.

Tabel 1. Presentase Jenis Kopi

\begin{tabular}{cc}
\hline Jenis kopi & Prosentase \\
\hline Kopi Arabika & $70 \%$ \\
\hline Kopi Robusta & $20 \%$ \\
\hline Kopi Liberika & $7 \%$ \\
\hline Kopi Excelsa & $3 \%$
\end{tabular}

Sumber : alamtani.com/jenis-kopi

Pada tabel 1. dapat ditarik kesimpulan bahwa penikmat kopi bukan hanya dari Indonesia saja tetapi mendunia. Tidak heran bahwa kopi merupakan menu wajib di setiap warung, kafe, kedai bahkan restoran. Dari mulai warung pinggir jalan, café, sampai restoran mewah maupun hotel berbintang pasti menyediakan kopi dengan variasi jenis dan harga yang berbeda. 
Kepopuleran kopi juga membawa dampak terhadap perkembangan bisnis, karena kini semakin banyak coffee shop atau café yang menjamur diwilayah ibu kota. Di Jakarta sendiri tercatat ada kurang lebih 528 coffee shop atau café. Di Indonesia, Coffee shop biasa disebut warung kopi atau kedai kopi. Coffee shop mulai hadir di tengah-tengah kita, mulai dari pelosok desa, hingga di pusat perkotaan. Coffee Shop bisa diartikan sebuah kafe kecil atau restoran kecil yang biasanya menjual kopi dan terkadang minuman non-alkohol, makanan sederhan atau snacks, dengan fasilitas yang menunjang di tempat tersebut. Senada dengan Wiktionary, pengertian coffee shop atau warung kopi sendiri dalam kamus besar Bahasa Indonesia karya Poerwadarminta adalah "sebuah tempat yang menjual kopi dan jenis minuman lain, serta makanan-makanan kecil dengan harga yang murah".

Banyaknya cooffe shop atau kafe yang bermunculan di tengah masyarakat membuat persaingan di antara bisnis kafe ini menjadi semakin ketat. Keputusan memilih kafe mana yang akan dijadikan tempat untuk melakukan kegiatan bagi masyarakat merupakan hal yang perlu mendapatkan perhatian bagi para pengasaha kafe. Keputusan pembelian merupakan keputusan yang diambil oleh masyarakat dalam memutuskan produk atau jasa mana yang akan dibeli untuk memenuhi kebutuhan hidupnya (Qomariah, 2015). Keputusan pembelian adalah pilihan masyarakat akan suatu produk atau jasa tertentu (Lupiyoadi, 2013). Ada banyak hal yang mempengaruhi keputusan pembelian disebuah coffee shop, misalnya harga produk, promosi, lokasi dan layanan yang diberikan oleh penyedian jasa. Harga merupakan jumlah rupiah yang harus dikeluarkan oleh konsumen untuk membeli suatu barang atau jasa (Buchari, 2011). Promosi merupakan upaya perusahaan utuk mengenalkan produknya kepada masyarakat (Tjiptono, 2014). Lokasi merupakan tempat dimana perusahaan melakukan aktivitas produksinya untuk menghasilkan barang dan jasa (Berman \& Evans., 2007).

Beberapa penelitian tentang bauran pemasaran yang dikaitkan dengan keputusan pembelian banyak yang sudah diilakukan. Penelitian yang dilakukan (Sandy, Arifin, \& Yaningwati, 2014) menyatakan bahwa promosi dapat meningkatkan keputusan pembelian. Penelitian (Sa'dullah \& Azhad, 2015)menyatakan bahwa kualitas layanan, harga produk dan lokasi perusahaan dapat meningkatkan keputusan pembelian pada perdagangan ikan di Pendaratan Pelelangan Ikan Pesisir Besuki Situbondo.Penelitian (Agustina, Sumowo, \& Wijayantini, 2018) memberikan hasil bahwa kualitas produk, dan harga meningkatkan masyarakat dalam melakukan pembelian. Penelitian (Hermawan, 2015) menyatakan bahwa marketing mix dapat meningkatkan keputusan pembelian.Penelitian (Apriliana \& Sumowo, 2015) menghasilkan bahwa variabel produk, variabel promosi, varibael tempat dan harga, semuanya berpengaruh signifikan terhadap keputusan pembelian smartphone merek Samsung. Penelitian (Napik, Qomariah, \& Santoso, 2018) menyatakan bahwa promosi berpengaruh terhadap keputusan pembelian BlackBerry. Penelitian (Sandy et al., 2014) menghasilkan bahwa promosi penjualan dapat meningkatkan pembelian yang dilakukan masyarakat.

Berkembangnya coffee shop yang salah satunya adalah Coffee Shop Warung kopi Cak Wang. Dimana Warung kopi Cak Wang adalah salah satu kedai kopi yang cukup terkenal dan menjadi favorit para mahasiswa, pelajar serta khalayak muda di kabupaten Jember. Kedai ini merupakan sarana pelepas penat dan bosan bagi masyarakat dengan menyediakan berbagai macam seduhan kopi spesial arabika dari seluruh daerah Indonesia dan food and beaverages lainnya dengan harga yang relatif terjangkau serta memberikan pelayanan yang cukup memuaskan. Di kota Jember terdapat beberapa warung kopi yang sangat terkenal di kalangan masyarakat Jember. Dari hal inilah hasil 
survey dari memperlihatkan rating cofee shop yang masuk ke dalam top brand index pada tabel 2.

Tabel 2: Kafe Yang Ada Di Kabupaten Jember Kota

\begin{tabular}{ccc} 
Cofee Shop & TBI & Quality \\
\hline Cak wang & $55 \%$ & Top \\
\hline Cofee tofie & $25 \%$ & Top \\
\hline Cafe Kolong & $15 \%$ & Middle \\
\hline Kopi Lowo & $5 \%$ & Lower \\
\hline
\end{tabular}

Sumber : cofeeshopjember.co.id

Dari sisi produk yang ditawarkan yaitu kopi, warung kopi Cak Wang memiliki diferensiasi yang unik. Pertama, warung kopi Cak Wang menyediakan ragam varian kopi arabika dari penjuru nusantara dengan harga yang relatif terjangkau. Kedua, di warung ini ada kopi yang disajikan dengan teknik pembuatan yang disebut Vietnam Drip. Khusus di Jember ini Cakwang memiliki dua cabang, yang pertama berada di jalan Mastrib yang kedua berada di jalan Semeru. CakWang merupakan Warung kopi yang terkenal di kalangan orang tua, pekerja, maupun mahasiswa. Dari hal inilah Cak Wang menduduki tempat pertama di Jember. Keberadaan kedai kopi khususnya kota Jember saat ini sangat banyak dan memiliki beragam varian yang ditawarkan. Salah satu kedai kopi yang menjadi pusat perhatian peniliti adalah warung kopi Cak Wang Jember. Warung Kopi Cak Wang ini menunjukkan pertumbuhan ekonomi yang sangat pesat. Peningkatan jumlah konsumen di warung kopi Cak Wang mengalami perkembangan yang cukup signifikan. Setiap hari rata-rata jumlah konsumen yang berkunjung ke warung kopi ini menembus 200 konsumen dari berbagai daerah yang terutama didominasi oleh mahasiswa. Dengan banyaknya pesaing yang ada di sekitar Kafe Cak Wang maka terdapat rumusan masalah yaitu bagaimana meningkatkan pembelian masyarakat pada Warung Cak Wang atas dasar harga, kualitas produk, promosi, lokasi dan layanan. Sedangkan tujuan dari peelitian ini adalah untuk mengetahui pengaruh harga, kualitas produk, promosi, lokasi dan layanan terhadap keputusan pembelian Warung Cak Wang Jember.

\section{METODE PENELITIAN}

Penelitian ini merupakan penelitian explanatory yaitu suatu metode penelitian yang bertujuan untuk mengetahui hubungan causal antara variabel independen terhadap variabel dependen (Sudana \& Setyanto, 2018). Penelitian ini menggunakan metode survei yang di dapat dari respon jawaban responden terhadap kuisioner. Variabel yang akan diteliti adalah variable harga, produk, promosi, lokasi dan layanan (variabel bebas) terhadap keputusan pembelian (variabel terikat). Populasi merujuk pada sekumpulan orang atau objek yang memiliki kesamaan dalam satu atau beberapa hal dan yang membentuk masalah pokok suatu riset khusus (Sugiyono, 2009). Populasi dalam penelitian ini adalah pelanggan dari Warung Kopi Cak Wang di Jember. Sampel itu sendiri merupakan subset dari sebuah populasi, terdiri dari beberapa anggota populasi (Ferdinand, 2006). Metode pengambilan sampel yang digunakan didalam penelitian ini adalah purposive sampling, yaitu pengambilan elemen-elemen yang dimasukkan didalam sampel dilakukan dengan sengaja, dengan catatan bahwa sample tersebut representative atau mewakili populasi (Arikunto, 2006). Pengambilan jumlah sampel penelitian minimal yaitu dengan mengalikan variabel dengan angka 5 sampai dengan 10 (Sugiyono, 2013). Mengacu pada jumlah sampel minimal yang harus diambil, maka 
variabel yang ada adalah sebanyak 6 dikalikan dengan angka 10, yaitu sebanyak 60 responden, karena jumlah veriabel yang diteliti adalah sebanyak 5 variabel bebas dan 1 variabel terikat.

Untuk menguji alat ukur maka digunakan uji validitas dan uji reliabilitas. Uji validitas bertujuan untuk mengetahui sejauh mana validitas data yang diperoleh dari penyebaran kuisioner. Uji validitas sebagai alat ukur dalam penelitian ini, yaitu menggunakan korelasi product moment pearson's (Ghozali, 2011). Uji reliabilitas digunakan untuk menguji kemampuan suatu hasil pengukuran relatif konsisten apabila pengukurannya diulangi dua kali atau lebih. Analisis regresi linier berganda digunakan untuk mengetahui pengaruh variabel bebas terhadap variabel terikat(Sugiyono, 2013).

\section{HASIL DAN PEMBAHASAN}

\section{Karakteristik Responden}

Responden dalam penelitian ini adalah seluruh pelanggan di Warung Kopi Cak Wang yang berjumlah 60 responden. Karakteristik responden dalam penelitian ini, yaitu karaktistik responden berdasarkan usia, jenis kelamin, dan profesi.

\section{Karakteristik Responden Berdasarkan Usia}

Usia responden terbagi dalam 3 kelompok dari 60 responden, yaitu $17-27$ tahun, 28 - 38 tahun, dan diatas 38 tahun.

Tabel 3. Karakteristik Responden Berdasarkan Usia

\begin{tabular}{ccc}
\hline \multirow{2}{*}{ Usia } & \multicolumn{2}{c}{ Jumlah } \\
\cline { 2 - 3 } & Jumlah & Persentase \\
\hline $17-27$ tahun & 32 & $5,34 \%$ \\
$28-38$ tahun & 22 & $36,66 \%$ \\
diatas 38 tahun & 6 & $10 \%$ \\
\hline Jumlah & 60 & $100 \%$ \\
\hline
\end{tabular}

Sumber : Data Diolah.

\section{Karakteristik Responden Berdasarkan Jenis Kelamin}

Jenis kelamin responden terbagi dalam 2 kelompok dari 60 responden, yaitu lakilaki dan perempuan.

Tabel 4: Karakteristik Responden Berdasarkan Jenis Kelamin

\begin{tabular}{ccc}
\hline \multirow{2}{*}{ Jenis Kelamin } & \multicolumn{2}{c}{ Jumlah } \\
\cline { 2 - 3 } & Jumlah & Persentase \\
\hline Laki & 53 & $88,34 \%$ \\
Perempuan & 7 & $11,66 \%$ \\
\hline Jumlah & 60 & $100 \%$ \\
\hline
\end{tabular}

Sumber : Data Diolah.

\section{Karakteristik Responden Berdasarkan Profesi}

Profesi responden terbagi dalam 3 kelompok dari 60 responden, yaitu, Pelajar, Wirausaha, dan Karyawan. 
Tabel 5: Karakteristik Responden Berdasarkan Profesi

\begin{tabular}{ccc}
\hline \multirow{2}{*}{ Profesi } & \multicolumn{2}{c}{ Jumlah } \\
\cline { 2 - 3 } & Jumlah & Persentase \\
\hline Pelajar & 44 & $73,33 \%$ \\
Wirausaha & 13 & $21,67 \%$ \\
Karyawan & 3 & $5 \%$ \\
\hline Jumlah & 60 & $100 \%$ \\
\hline
\end{tabular}

Sumber : Data Diolah.

\section{Hasil Uji Validitas}

Uji validitas dimaksudkan untuk mengetahui seberapa besar ketepatan dan kecermatan suatu alat ukur dalam melakukan fungsi ukurnya.

Tabel 6: Hasil Uji Validitas

\begin{tabular}{ccccc}
\hline Indikator & $\begin{array}{c}\text { Product Moment } \\
\text { Pearson's }\end{array}$ & Sig. & $\boldsymbol{a}$ & Keterangan \\
\hline $\mathrm{X}_{1.1}$ & 0,685 & $0,000<0,05$ & Valid \\
$\mathrm{X}_{1.2}$ & 0,638 & $0,000<0,05$ & Valid \\
$\mathrm{X}_{1.3}$ & 0,763 & $0,000<0,05$ & Valid \\
$\mathrm{X}_{2.1}$ & 0,570 & $0,000<0,05$ & Valid \\
$\mathrm{X}_{2.2}$ & 0,649 & $0,000<0,05$ & Valid \\
$\mathrm{X}_{2.3}$ & 0,696 & $0,000<0,05$ & Valid \\
$\mathrm{X}_{3.1}$ & 0,699 & $0,000<0,05$ & Valid \\
$\mathrm{X}_{3.2}$ & 0,761 & $0,000<0,05$ & Valid \\
$\mathrm{X}_{3.3}$ & 0,697 & 0,000 & $<0,05$ & Valid \\
$\mathrm{X}_{4.1}$ & 0,670 & $0,000<0,05$ & Valid \\
$\mathrm{X}_{4.2}$ & 0,627 & $0,000<0,05$ & Valid \\
$\mathrm{X}_{4.3}$ & 0,632 & $0,000<0,05$ & Valid \\
$\mathrm{X}_{5.1}$ & 0,732 & $0,000<0,05$ & Valid \\
$\mathrm{X}_{5.2}$ & 0,649 & $0,000<0,05$ & Valid \\
$\mathrm{X}_{5.3}$ & 0,742 & $0,000<0,05$ & Valid \\
$\mathrm{Y}_{1}$ & 0,719 & $0,000<0,05$ & Valid \\
$\mathrm{Y}_{2}$ & 0,656 & $0,000<0,05$ & Valid \\
$\mathrm{Y}_{3}$ & 0,720 & $0,000<0,05$ & Valid \\
\hline
\end{tabular}

Sumber : Data Diolah.

Berdasarkan tabel 6 diketahui bahwa masing-masing indikator (item) dalam variabel yang digunakan mempunyai hasil nilai product moment pearson's dengan signifikasi $0,000<0,05$, sehingga indikator (item) yang digunakan dalam variabel penelitian ini dapat dinyatakan sesuai atau relevan dan dapat digunakan sebagai item dalam pengumpulan data.

\section{Hasil Uji Reliabilitas}

Pengujian ini dilakukan untuk menunjukkan sejauh mana suatu hasil pengukuran relatif konsisten. Suatu pertanyaan atau peryataan yang baik adalah pertanyaan atau peryataan yang jelas mudah dipahami dan memiliki interpretasi yang sama meskipun disampaikan kepada responden yang berbeda dan waktu yang berlainan. 
Tabel 7: Hasil Uji Reliabilitas

\begin{tabular}{ccccc}
\hline Variabel & Cronbach's Alpha & Cutt off & N of Item & Keterangan \\
\hline $\mathrm{X}_{1}$ & 0,761 & $>0,6$ & 3 & Reliabel \\
$\mathrm{X}_{2}$ & 0,727 & $>0,6$ & 3 & Reliabel \\
$\mathrm{X}_{3}$ & 0,736 & $>0,6$ & 3 & Reliabel \\
$\mathrm{X}_{4}$ & 0,747 & $>0,6$ & 3 & Reliabel \\
$\mathrm{X}_{5}$ & 0,704 & $>0,6$ & 3 & Reliabel \\
$\mathrm{Y}$ & 0,776 & $>0,6$ & 3 & Reliabel \\
\hline
\end{tabular}

Sumber : Data Diolah.

Berdasarkan 7, hasil uji reliabilitas diatas menunjukkan bahwa data yang diperoleh bersifat reliabel karena nilai Cronbach's Alpha yakni 0,761, 0,727, 0,736, 0,747, 0,704 dan $0,776>0,60$, sehingga data yang diperoleh dapat dinyatakan reliabel atau layak sebagai alat dalam pengumpulan data.

\section{Hasil Analisis Regresi Linear Berganda}

Analisis regresi berganda berkaitan dengan studi ketergantungan suatu variabel dependen pada satu atau lebih variabel independen dengan tujuan untuk mengetahui seberapa besar pengaruh variabel independen terhadap variabel dependen. Hasil analisis regresi linear berganda antara variabel independen yaitu harga, produk, promosi lokasi dan layanan, serta variabel dependen yaitu pembelian pada tabel 8 .

\section{Tabel 8: Hasil Regresi Linear Berganda}

\begin{tabular}{|c|c|c|c|c|c|c|c|}
\hline \multirow{2}{*}{$\begin{array}{c}\text { Variabel } \\
\text { Independent }\end{array}$} & Unstandardized & \multirow[t]{2}{*}{$\mathrm{T}$} & \multirow{2}{*}{\multicolumn{2}{|c|}{ ttabel }} & \multirow[t]{2}{*}{ Sig. } & \multirow[t]{2}{*}{$a$} & \multirow[t]{2}{*}{ Keterangan } \\
\hline & Coefficients $B$ & & & & & & \\
\hline (Constant) & $-0,427$ & & - & & & - & - \\
\hline Harga $\left(\mathrm{X}_{1}\right)$ & 0,201 & 2,212 & $>$ & 2,004 & 0,031 & $<0,05$ & Signifikan \\
\hline Produk $\left(\mathrm{X}_{2}\right)$ & 0,252 & 3,978 & $>$ & 2,004 & 0,000 & $<0,05$ & Signifikan \\
\hline Promosi $\left(\mathrm{X}_{3}\right)$ & 0,211 & 2,294 & $>$ & 2,004 & 0,026 & $<0,05$ & Signifikan \\
\hline Lokasi $\left(\mathrm{X}_{4}\right)$ & 0,225 & 2,681 & $>$ & 2,004 & 0,010 & $<0,05$ & Signifikan \\
\hline Layanan $\left(\mathrm{X}_{5}\right)$ & 0,215 & 2,947 & $>$ & 2,004 & 0,005 & $<0,05$ & Signifikan \\
\hline \multicolumn{2}{|c|}{ Adjusted $R$ Square $=0,872$} & & & & $\begin{array}{l}\text { F. Hitu } \\
\text { Sig. F }\end{array}$ & $\begin{array}{l}\mathrm{ng}=81, \\
=0,000\end{array}$ & \\
\hline
\end{tabular}

Sumber : Data Diolah.

\section{Pembahasan}

\section{Pengaruh Harga Terhadap Pembelian}

Hasil penelitian menunjukkan bahwa nilai koefisien variabel harga sebesar 0,201 atau 20,1\% dengan arah positif. Harga sebagai nilai yang harus dikeluarkan oleh seorang pelanggan dalam mendapatkan suatu barang atau jasa adalah baik, dengan artian lainnya bahwa adanya harga yang ditawakan untuk berbagai menu yang ada di Warung Cak Wang yang dirasa relatif terjangkau, adanya harga yang kompetitif dengan warung atau penawaran sejenis lainnya, dan adanya kesesuaian nilai yang didapatkan pelanggannya terhadap nilai uang telah mereka keluarkan, telah menjadikan pelanggan merasa sesuai 
terhadap penawaran harga yang diberikan oleh usaha Warung Cak Wang, selain itu adanya harga akan menjadi daya tarik sendiri bagi pelanggannya dalam mendapatkan sebuah nilai yang dianggap pantas terhadap pengeluaran yang telah dilakukan oleh pelanggannya dan dengan begitu maka pembelian yang dilakukan oleh pelanggannya merupakan pembelian yang relatif tepat karena nilai yang dikeluarkan sebanding dengan nilai yang didapatkan.

\section{Pengaruh Produk Terhadap Keputusan Pembelian}

Hasil penelitian menunjukkan bahwa nilai koefisien variabel produk sebesar 0,252 atau 25,2\% dengan arah positif. Produk sebagai keunggulan yang ada didalam sebuah produk yang ditawarkan oleh penyedia produk untuk pelanggannya adalah baik, dengan artian lainnya bahwa adanya produk makanan dan minuman yang ditawarkan dan disediakan cukup beraneka ragam, adanya produk makanan dan minuman yang disediakan cukup berkualitas dan nyaman bagi pelanggannya, dan adanya produk yang makanan dan minuman yang ditawarkan dan disediakan higienis dan layak untuk dikonsumsi, telah menjadi pertimbangan bagi pelanggannya dalam menentukan pilihannya dalam berkunjung, membeli dan menikmati makanan yang disediakan di Warung Cak, selain itu makanan dan minuman yang ditawarkan merupakan hidangan makanan dan minuman yang sangat sesuai dengan kondisi para pelanggannya untuk menikmati suasana bersantai dan berkumpul bersama kerabatnya.

\section{Pengaruh Promosi Terhadap Keputusan Pembelian}

Hasil penelitian menunjukkan bahwa nilai koefisien variabel promosi sebesar 0,211 atau $21,1 \%$ dengan arah positif. Promosi sebagai cara yang dilakukan oleh penyedia atau pengusaha dalam memasarkan produk atau jasanya dengan menginformasikan dan mengingatkan pelangganya dengan cara yang dianggap pantas adalah baik, dengan artian lain bahwa adanya publisitas yang dilakukan dimedia jejaring sosial media atau internet, adanya logo atau nama brand yang mengingatkan pelanggannya, adanya kegiatan atau event yang sering diadakan di Warung Cak Wang, telah merangsang pelanggan untuk dapat mengingat dengan mudah nama atau brand dari Warung Cak Wang sehingga pelanggan yang akan menentukan pilihannya dalam membeli disebuah Warung Sejenis akan mempertimbangkan kembali reputasi yang ada pada Warung Cak Wang, selain itu promosi yang ada dimedia sosial akan senantiasa terbaharui oleh adanya informasi - informasi baru yang ada di seputar Warung Cak Wang yang akan dapat mengingatkan pelanggannya dalam membeli.

\section{Pengaruh Lokasi Terhadap Keputusan Pembelian}

Hasil penelitian menunjukkan bahwa nilai koefisien variabel lokasi sebesar 0,225 atau 22,5\% dengan arah positif. Lokasi sebagai tempat usaha ditawarkannya makanan dan minuman yang disediakan oleh pengusaha untuk para pelanggannya adalah baik, dengan artian lain bahwa adanya jangkauan ke lokasi yang dirasa mudah dijangkau oleh pelanggannya, adanya atau tersedianya lokasi parkir yang luas dan aman bagi pelanggannya, dan adanya lingkungan Warung Cak Wang yang nyaman untuk bersantai, menyenangkan dan tenang bagi pelanggannya, telah menjadikan pelanggan merasa nyaman dalam berkunjung karena suasana yang ada merupakan salah satu faktor utama pelanggan dalam berkunjung, suasana yang ada akan menjadikan pertimbangan pelanggan dalam menentukan pilihannya dalam berkunjung karena usaha sejenis yang ada relatif sangat kompetitif dalam menyediakan tempat atau lokasi yang juga dirasa nyaman oleh pengunjungnya. 


\section{Pengaruh Layanan Terhadap Keputusan Pembelian}

Hasil penelitian menunjukkan bahwa nilai koefisien variabel layanan sebesar 0,215 atau $21,5 \%$ dengan arah positif. Layanan sebagai kehandalan pelayan dalam menyediakan berbagai macam kebutuhan yang diminta oleh pelanggannya adalah baik, dengan artian lain bahwa adanya sikap dan perilaku karyawan yang ramah dalam melayani pelanggannya, adanya pelayanan yang segera dan cepat dalam menyajikan permintaan dari pelanggannya, dan adanya pelayan atau pelayanan yang bersedia menerima keluhan dari pelangganya terhadap pelayanan yang ada, telah menjadikan pelanggannya merasa nyaman dalam memesan kebutuhan yang dibutuhkannya dengan segera sehingga permintaan yang dilakukan dengan segera akan menjadi suatu pengalaman terhadap kehandalan pelayanan yang disediakan bagi pengunjunganya, maka pengalaman yang ada akan menjadi ingatan dalam menentukan piihan dan alternatif pembeliannya atau kunjungan pada masa periode atau waktu yang akan datang.

\section{Kesimpulan}

\section{KESIMPULAN DAN SARAN}

Harga berpengaruh positif terhadap keputusan pembelian pelanggan di Warung Kopi Cak Wang. Dimana Variabel harga $\left(X_{1}\right)$ memiliki nilai t 2,212 > 2,004 dan signifikasi 0,031 < 0,05, maka Ho ditolak dan Ha diterima, yang berarti secara parsial variabel harga berpengaruh signifikan terhadap keputusan pembelian pelanggan di Warung Kopi Cak Wang. Produk berpengaruh positif terhadap keputusan pembelian pelanggan di Warung Kopi Cak Wang. Dimana Variabel produk $\left(\mathrm{X}_{2}\right)$ memiliki nilai $\mathrm{t}$ 3,978 > 2,004 dan signifikasi 0,000 < 0,05, maka Ho ditolak dan Ha diterima, yang berarti secara parsial variabel produk berpengaruh signifikan terhadap keputusan pembelian pelanggan di Warung Kopi Cak Wang. Promosi berpengaruh positif terhadap keputusan pembelian pelanggan di Warung Kopi Cak Wang. Dimana Variabel promosi $\left(\mathrm{X}_{3}\right)$ memiliki nilai t 2,294 > 2,004 dan signifikasi 0,026 < 0,05, maka Ho ditolak dan Ha diterima, yang berarti secara parsial variabel promosi berpengaruh signifikan terhadap keputusan pembelian pelanggan di Warung Kopi Cak Wang. Lokasi berpengaruh positif terhadap keputusan pembelian pelanggan di Warung Kopi Cak Wang. Dimana Variabel lokasi $\left(\mathrm{X}_{4}\right)$ memiliki nilai t 2,681 > 2,004 dan signifikan $0,010<0,05$, maka Ho ditolak dan Ha diterima, yang berarti secara parsial variabel lokasi berpengaruh signifikan terhadap keputusan pembelian pelanggan di Warung Kopi Cak Wang. Layanan berpengaruh positif terhadap keputusan pembelian pelanggan di Warung Kopi Cak Wang. Dimana Variabel layanan $\left(X_{5}\right)$ memiliki nilai t 2,947> 2,004 dan signifikan 0,005 $<0,05$, maka Ho ditolak dan Ha diterima, yang berarti secara parsial variabel layanan berpengaruh signifikan terhadap keputusan pembelian pelanggan di Warung Kopi Cak Wang.

\section{Saran}

Pihak Pengusaha Warung Cak Wang dihimbau lebih sesuai dalam menentukan harga yang ditawarkan sehingga pelanggan tetap tertarik terhadap produk yang ditawarkan. Pihak Pengusaha Warung Cak Wang dihimbau lebih meningkatkan keragaman produk makanan dan minuman yang ditawarkan sehingga merasa nyaman dalam memesan makanan dan minuman yang dibutuhkannya. Pihak Pengusaha Warung Cak Wang dihimbau meningkatkan promosi melalui media sosial, penggunaan banner, dan lain sebagainya, sehingga pelanggan akan tetap mengingat apa saja yang ditawarkan di Warung Cak Wang. ihak Pengusaha Warung Cak Wang dihimbau lebih meningkatkan kecepatan pelayanan yang ada. 


\section{DAFTAR REFERENSI}

Agustina, N. A., Sumowo, S., \& Wijayantini, B. (2018). PENGARUH KUALITAS PRODUK, CITRA MEREK, DAN HARGA TERHADAP KEPUTUSAN PEMBELIAN. Jurnal Peneliti, 3(2), 186-196.

Apriliana, H. T. A., \& Sumowo, S. (2015). Analisis Variabel-Variabel yang Mempengaruhi Kepuusan Pembelian Smartphome Android Merek Samsung (Studi Kasus: Mahasiswa Fakultas Ekonomi Manajemen Universitas Muhammadiyah Jember 2011-2013). Jurnal Manajemen Dan Bisnis Indonesia, 1(2), 121-142. Retrieved from http://jurnal.unmuhjember.ac.id/index.php/JMBI/article/viewFile/13/11

Arikunto, S. (2006). Prosedur Penelitian Suatu Pendekatan Praktek. Jakarta: PT Rineka Cipta.

Berman, B., \& Evans., J. R. (2007). Retail Management. New Jersey: Prentice Hall.

Buchari, A. (2011). Manajemen Pemasaran dan Pemasaran Jasa. Bandung: Penerbit Alfabeta.

Ferdinand, A. (2006). Metode Penelitian Manajemen:Pedoman Penelitian Untuk Penulisan Skripsi, Thesis, dan Disertasi Ilmu Manajemen. Semarang: Badan Penerbit Universitas Diponegoro.

Ghozali, I. (2011). Aplikasi Analsiis Multivariate dengan Program SPSS. Semarang: BP Universitas Diponegoro.

Hermawan, H. (2015). ANALISIS PENGARUH BAURAN PEMASARAN TERHADAP KEPUTUSAN, KEPUASAN DAN LOYALITAS KONSUMEN DALAM PEMBELIAN ROTI CERIA DI JEMBER Haris. Jurnal Manajemen Dan Bisnis Indonesia, 1(2), 143-161.

Kotler, P., \& Armstrong, G. (2012). Principles of Marketing. New Jersey: Prentice Hall.

Kotler, P., \& Keller, K. L. (2009). Manajemen Pemasaran. Jakarta: Penerbit PT. Indeks,. Lupiyoadi, R. (2013). Manajemen Pemasaran. Jakarta: Salemba Empat.

Napik, A., Qomariah, N., \& Santoso, B. (2018). Kaitan Citra Merek, Persepsi Harga, Kualitas Produk, Dan Promosi Terhadap Keputusan Pembelian Blackberry. Jurnal Penelitian IPTEKS, 3(1), 73. https://doi.org/10.32528/ipteks.v3i1.1880

Qomariah, N. (2015). Marketing Adactive Strategy. Jember: CV. Cahaya Ilmu.

Sa'dullah, \& Azhad, M. N. (2015). Analisis persepsi kualitas layanan, harga dan lokasi terhadap keputusan perdagangan ikan. Jurnal Manajemen Dan Bisnis Indonesia, 1(1), 61-75. Retrieved from http://jurnal.unmuhjember.ac.id/index.php/JMBI/article/viewFile/15/13

Sandy, F., Arifin, Z., \& Yaningwati, F. (2014). PENGARUH BAURAN PROMOSI TERHADAP KEPUTUSAN PEMBELIAN (Survei pada Mahasiswa Jurusan Bisnis Angkatan 2010-2012 Fakultas Ilmu Administrasi Pengguna Indosat di Universitas Brawijaya) Febryan. Jurnal Administrasi Bisnis (JAB), 9(2), 1-10. Retrieved from http://administrasibisnis.studentjournal.ub.ac.id/index.php/jab/article/view/412/608

Sudana, I. M., \& Setyanto, R. H. (2018). Metode Penelitian Bisnis dan Analisis Data Dengan SPSS. Jakarta: Penerbit Erlangga.

Sugiyono. (2009). Metode Penelitian Kuantitatif, Kualitatif, dan R\&D. Bandung: Alfabeta.

Sugiyono. (2013). Metode Penelitian Pendidikan Pendekatan Kuantitatif, Kualitatif, dan $R \& D$. Bandung: Alfabeta.

Tjiptono, F. (2014). Pemasaran Jasa (Prinsip, Penerapan, Penelitian. Yogyakarta: Andi. 